\title{
Brief report: RRx-001 is a c-Myc inhibitor that targets cancer stem cells
}

\author{
Bryan Oronsky ${ }^{1}$, Tony R. Reid ${ }^{2}$, Arnold Oronsky ${ }^{3}$, Scott Caroen ${ }^{1}$, Corey A. Carter ${ }^{1}$ \\ and Pedro Cabrales ${ }^{4}$ \\ ${ }^{1}$ EpicentRx Inc, San Diego, CA 92121, USA \\ ${ }^{2}$ Moores Cancer Center, University of California San Diego, La Jolla, CA 92093, USA \\ ${ }^{3}$ InterWest Partners, Menlo Park, CA 94025, USA \\ ${ }^{4}$ Department of Bioengineering, University of California San Diego, La Jolla, CA 92093, USA \\ Correspondence to: Bryan Oronsky, email: info@epicentrx.com \\ Keywords: cancer stem cell; c-Myc; Wnt pathway; RRx-001; resistance reversal \\ Received: March 20, $2018 \quad$ Accepted: April 08, $2018 \quad$ Published: May 04, 2018 \\ Copyright: Oronsky et al. This is an open-access article distributed under the terms of the Creative Commons Attribution License \\ 3.0 (CC BY 3.0), which permits unrestricted use, distribution, and reproduction in any medium, provided the original author and \\ source are credited.
}

\section{ABSTRACT}

The goal of anticancer therapy is to selectively eradicate all malignant cells. Unfortunately for the majority of patients with metastatic disease, this goal is consistently thwarted by the nearly inevitable development of therapeutic resistance; the main driver of therapeutic resistance is a minority subpopulation of cancer cells called cancer stem cells (CSCs) whose mitotic quiescence essentially renders them non-eradicable. The $W n t$ signaling pathway has been widely implicated as a regulator of CSCs and, therefore, its inhibition is thought to result in a reversal of therapeutic resistance via loss of stem cell properties.

RRX-001 is a minimally toxic redox-active epi-immunotherapeutic anticancer agent in Phase III clinical trials that sensitizes tumors to radiation and cytotoxic chemotherapies. In this article, as a potential mechanism for its radio- and chemosensitizing activity, we report that $R R x-001$ targets $C D 133^{+} / \mathrm{CD}_{4} 4^{+}$cancer stem cells from three colon cancer cell-lines, HT-29, Caco-2, and HCT116, and inhibits Wnt pathway signalling with downregulation of c-Myc.

\section{INTRODUCTION}

The c-Myc (Myc) oncoprotein is a well-established driver of breast, lung, colorectal and prostate cancers that is currently considered "undruggable" [1-4]. Myc overexpression is associated with cancer stem cell maintenance [5] and, by extension, with therapeutic resistance since cancer stem cells are thought to be the primary mediators of tumor resistance and progression. RRx-001 is a first-in-class minimally toxic epiimmunotherapeutic agent in Phase III clinical trials as a chemosensitizer to reverse resistance in small cell lung cancer (SCLC), high-grade neuroendocrine carcinomas (HGNEC) and colorectal cancers [6].

Herein, as a potential mechanism for its radio- and chemosensitizing activity, we demonstrate for the first time that RRx-001 targets cancer stem cells (CSCs) and that it decreases the expression levels of Wnt pathway components and target genes, such as TCF4, Pygo2, Axin2 and c-Myc, which are known to govern stem cell renewal and differentiation $[7,8]$.

\section{RESULTS}

RRx-001 selectively targets colon CSCs

CD133 and CD44 are widely considered as markers of cancer stem/progenitor-like cells. In order to determine the effect of RRx-001 on both cancer and CSC cell proliferation, an MTT assay was performed.

Results of the flow cytometric assay depicted that after 3-day treatment, $\mathrm{RRx}-001$ reduced the $\mathrm{CD} 133^{+} /$ 
CD $44^{+}$population in a time-dependent manner in all three cell lines. The extent of reduction was less than that of non-CSC cancer cells (Figure 1).

\section{RRx-001 downregulates components of the Wnt pathway}

To test the hypothesis that downregulation of the Wnt signalling pathway is responsible for the reduced CSC growth, since the Wnt signaling pathway is reported to sustain self-renewal potential and chemoresistance in CSCs $[9,10]$, the impact of RRx-001 on the Wnt pathway was investigated. (Figure 2) As shown in Figure 3, RRx-001 dramatically decreased expression levels of Axin2 and c-Myc.

\section{DISCUSSION}

In light of the failure of currently available therapeutic options to eliminate CSCs, which are associated with treatment resistance and cancer recurrence, CSC-targeted therapies have the potential to usher in a new paradigm shift in oncology (Figure 3).

\section{MATERIALS AND METHODS}

\section{RRx-001}

RRx-001, provided by EpicentRx, Inc, was diluted in dimethylsulfoxide (DMSO) to a $10 \mu \mathrm{M}$ concentration.

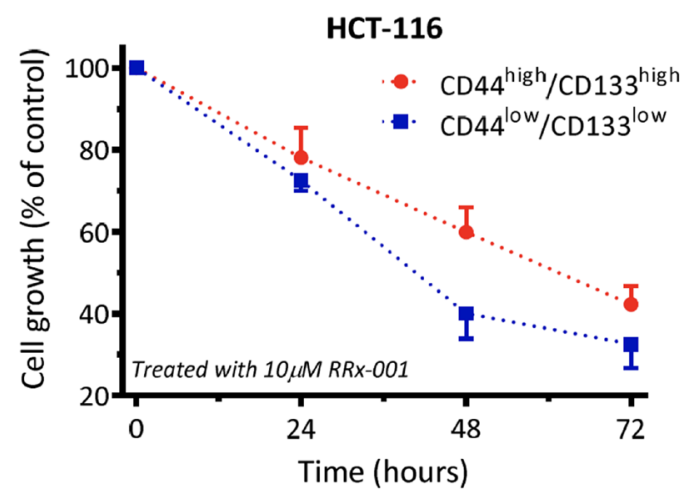

\section{Fluorescence-activated cell sorting (FACS) of cells}

Colon cancer cell lines Caco-2, HT-29, and HCT116 were obtained from the American Type Culture Collection (ATCC, Rockville, MD, USA), and maintained according to the ATCC's instructions. All culture reagents were from Invitrogen (Carlsbad, CA, USA). To analyze the expression of CD44 and CD133 in different lines, cells were treated with $10 \mu \mathrm{M} R R x-001$ for 72 hours, then trypsin-digested and re-suspended in stain buffer $\left(1 \times 10^{6}\right.$ cells in $\left.80 \mu \mathrm{l}\right)$. Cells were then treated with 20 $\mu \mathrm{FcR}$ Blocking Reagent for $15 \mathrm{~min}$, and incubated with antibodies (human anti-CD44-FITC and human anti-CD133-PE) for $30 \mathrm{~min}$. After staining, cells were subjected to flow cytometry.

To isolate $\mathrm{CD} 44^{\text {high }} / \mathrm{CD} 133^{\text {high }}$ and $\mathrm{CD} 44^{\text {low }} / \mathrm{CD} 133^{\text {low }}$ cells were trypsinized and blocked with FcR Blocking Reagent. Propidium iodide staining was applied to exclude the dead cells. Live cells were incubated with antibodies (human anti-CD44-FITC and human anti-CD133-APC) for $30 \mathrm{~min} . \mathrm{CD} 44^{\text {low }} / \mathrm{CD} 133^{\text {low }}$ and $\mathrm{CD} 44^{\text {high }} / \mathrm{CD} 133^{\text {high }}$ cells were sorted by a cell sorter.

\section{Cell proliferation measurement}

The colon cancer cells were split into 96 well dishes at 2,000 cells per well. Cells were treated with $10 \mu \mathrm{M}$ of RRx-001. Cell proliferation was evaluated using the MTT (3-[4,5-dimethylthiazol-2-yl]-2,5-diphenyl tetrazolium

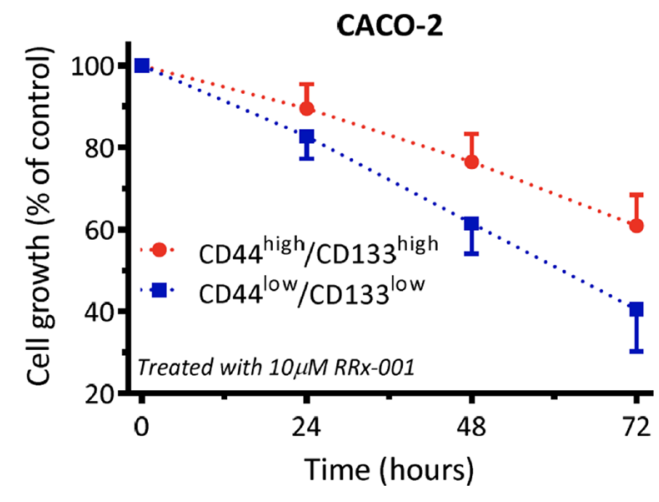

Figure 1: RRx-001 inhibits proliferation of colon cancer cells and stem cells in all three cell lines. 


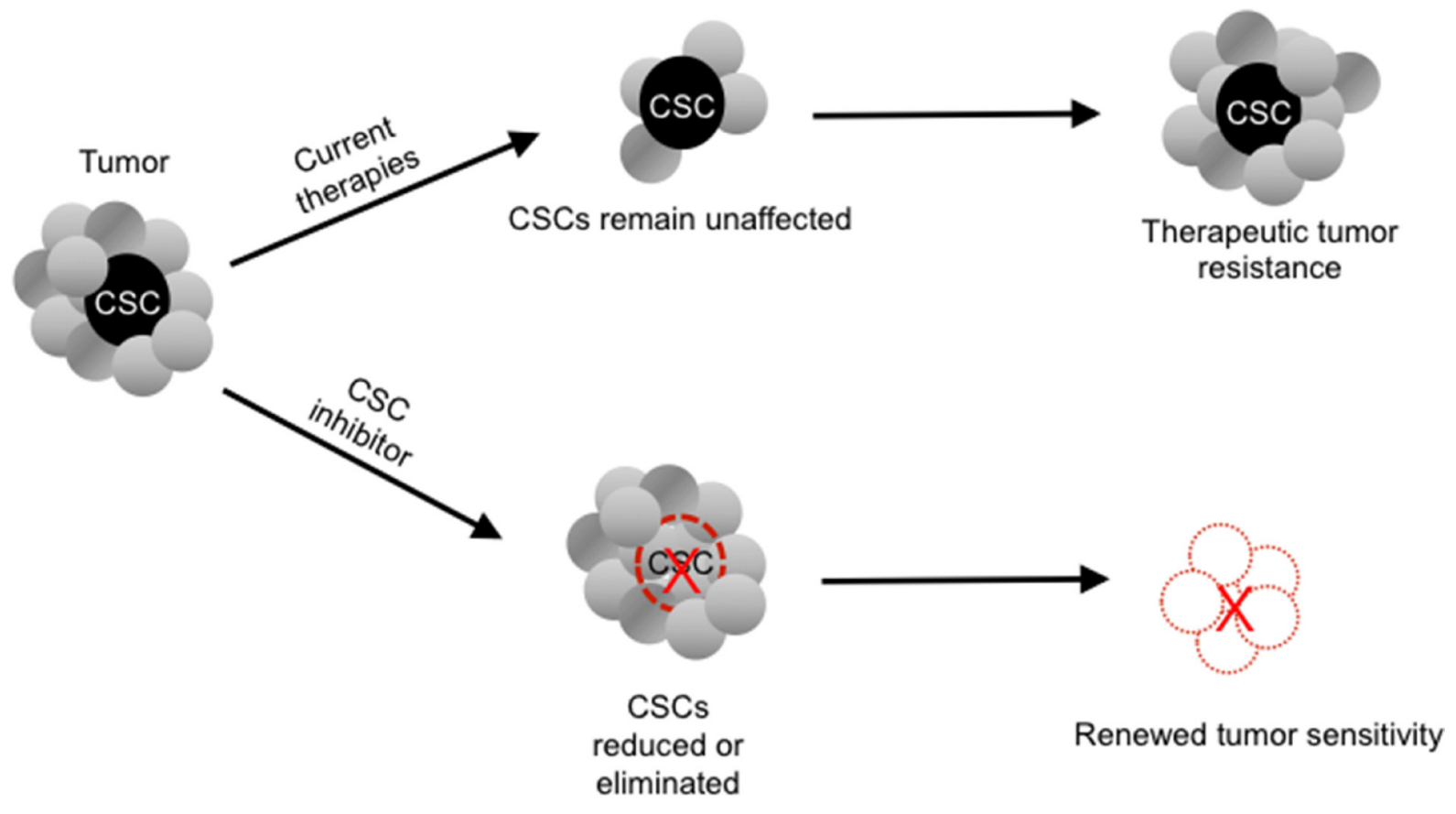

Figure 2: Potential paradigm-shifting effect of a cancer stem cell (CSC) inhibitor on tumor chemoresistance.

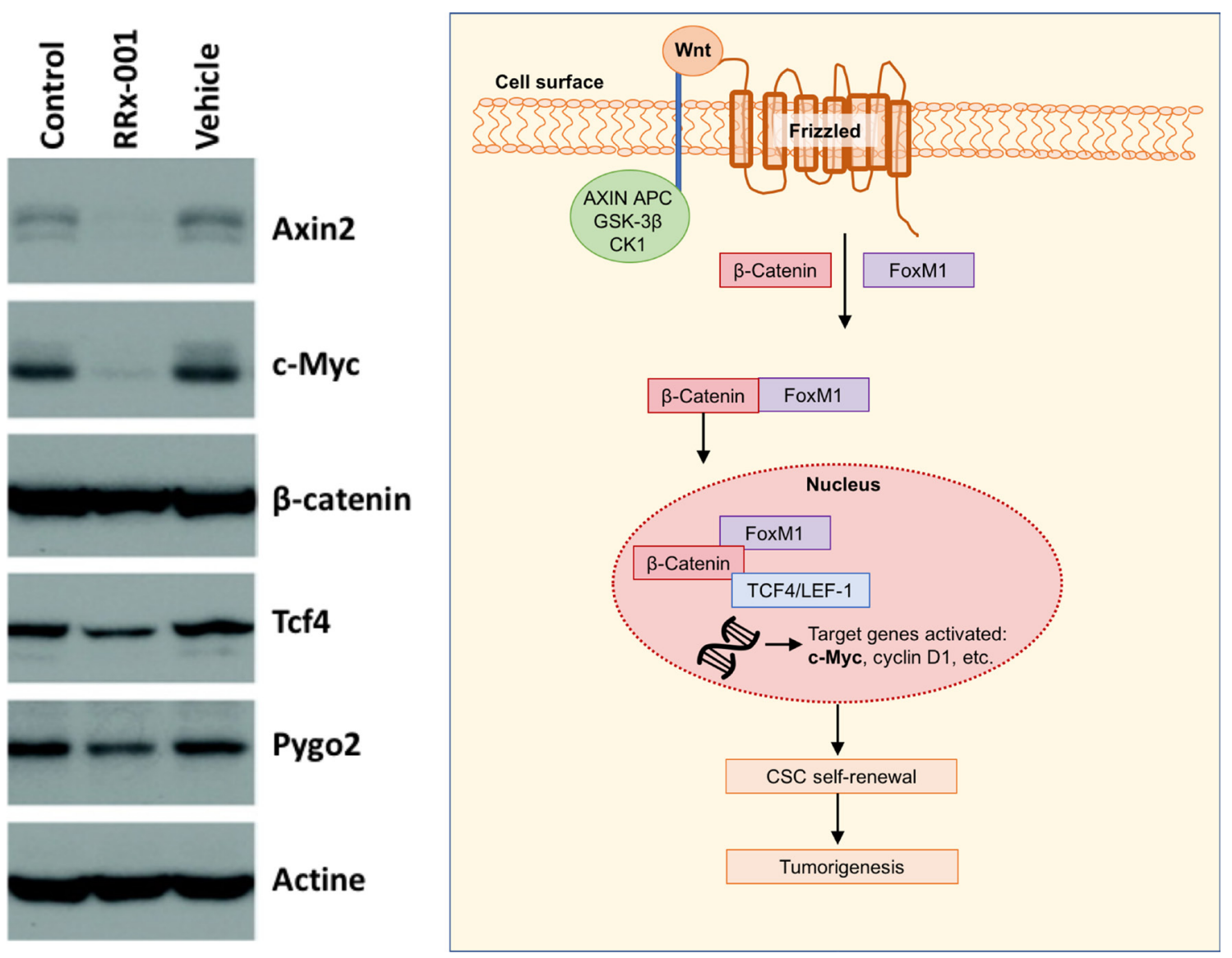

Figure 3: Western blot of analysis of Wnt target genes with Wnt pathway shown to the right. 
bromide) assay at indicated days. The absorbance was measured at the wavelength of $570 \mathrm{~nm}$. The measured optical density (OD) values were directly proportional to the number of viable cells. Then,

dose-response curves were fitted to the data. All experiments were repeated at least three times.

\section{Western blot for protein expression}

Whole-cell lysates were separated by $10 \%$ SDSPAGE and proteins were analyzed by western blotting for the expression of Axin 2, c-Myc, $\beta$-catenin, Tcf4, and Pygo2. Actin was used as a loading control.

\section{Statistical analysis}

All data were presented as mean \pm SD from three sets of independent experiments and analyzed using statistical software GraphPad Prism. Statistical differences between groups were determined by unpaired Student's $t$-test or One-way Analysis of Variance (ANOVA); $P<0.05$ was considered as statistical significance.

\section{CONCLUSIONS}

Herein, we demonstrate for the first time that RRx001 targets colon CSCs and inhibits multiple components of the self-renewal Wnt pathway including c-Myc. Since Myc is not an easily "druggable" protein, due to a lack of enzymatic activity or any small molecule-binding deep pockets [11], these results suggest that RRx-001 should be evaluated as a treatment for c-Myc-overexpressing tumors.

\section{CONFLICTS OF INTEREST}

The authors declare that EpicentRx, Inc. funds research of RRx-001.

\section{FUNDING}

No funding was received for the writing of this manuscript.

\section{REFERENCES}

1. Fletcher S, Prochownik EV. Small-Molecule Inhibitors of the Myc Oncoprotein. Biochim Biophys Acta.
2015; 1849:525-543. https://doi.org/10.1016/j. bbagrm.2014.03.005.

2. Beroukhim R, Mermel CH, Porter D, Wei G, Raychaudhuri S, Donovan J, Barretina J, Boehm JS, Dobson J, Urashima M, McHenry KT, Pinchback RM, Ligon AH, et al. The landscape of somatic copy-number alteration across human cancers. Nature. 2010; 463:899-905. https://doi. org/10.1038/nature08822.

3. Zaytseva O, Quinn LM. DNA Conformation Regulates Gene Expression: The MYC Promoter and Beyond. BioEssays. 2018; 40:1700235. https://doi.org/10.1002/ bies. 201700235.

4. You Z, Saims D, Chen S, Zhang Z, Guttridge DC, Guan KI, MacDougald OA, Brown AM, Evan G, Kitajewski J, Wang CY. Wnt signaling promotes oncogenic transformation by inhibiting c-Myc-induced apoptosis. J Cell Biol. 2002; 157:429-440. https://doi.org/10.1083/jcb.200201110.

5. Whitfield JR, Soucek L. Tumor microenvironment: Becoming sick of Myc. Cell Mol Life Sci. 2012; 69:931934. https://doi.org/10.1007/s00018-011-0860-x.

6. Oronsky B, Scicinski J, Ning S, Peehl D, Oronsky A, Cabrales P, Bednarski M, Knox S. Rockets, radiosensitizers, and RRx-001: an origin story part I. Discov Med. 2016; 21:173-80.

7. Clevers H, Nusse R. Wnt/ $\beta$-Catenin Signaling and Disease. Cell. 2012; 149:1192-205. https://doi.org/10.1016/j. cell.2012.05.012.

8. Yang K, Wang X, Zhang H, Wang Z, Nan G, Li Y, Zhang F, Mohammed MK, Haydon RC, Luu HH, Bi Y, He TC. The evolving roles of canonical WNT signaling in stem cells and tumorigenesis: Implications in targeted cancer therapies. Lab Invest. 2016; 96:116-136. https://doi.org/10.1038/ labinvest.2015.144.

9. Basu S, Haase G, Ben-Ze'ev A. Wnt signaling in cancer stem cells and colon cancer metastasis. F1000Research. 2016; 5:F1000 Faculty Rev-699. https://doi.org/10.12688/ f1000research.7579.1.

10. Polakis P. Drugging Wnt signalling in cancer. EMBO J. 2012; 31:2737-2746. https://doi.org/10.1038/emboj.2012.126.

11. Kiessling A, Sperl B, Hollis A, Eick D, Berg T. Selective inhibition of c-Myc/Max dimerization and DNA binding by small molecules. Chem Biol. 2006; 13:745-51. https://doi. org/10.1016/j.chembiol.2006.05.011. 